\title{
СИСТЕМНО-ІНТЕГРАТИВНИЙ ПІДХІД У ФОРМУВАННІ ТВОРЧОЇ ОСОБИСТОСТІ МАЙБУТНЬОГО ВЧИТЕЛЯ В УМОВАХ ПЕДАГОГІЧНОГО ВИШУ
}

Потапенко О. Б., Іванова В. В. Системно-інтегративний підхід у формуванні творчої особистості майбутнього вчителя в умовах педагогічного вишу.

У статті розглянуто проблему використання системно-інтегративного підходу у формуванні творчої особистості майбутнього вчителя в умовах педагогічного вишу. Автори статті доходять до висновку про значне зростання в умовах розвитку постіндустріального суспільства вимог щодо виховання ініціативної, соціально активної, творчо спрямованої особистості, спроможної ефективно розв'язувати життєві проблеми; підкреслюють важливість активізації й модернізації пізнавальної діяльності студентів педагогічних вишів шляхом системного аналізу організації й змісту навчально-виховного процесу, зведення окремих його аспектів у єдину модель.

Ключові слова: творчість, творчі здібності, системно-інтегрований підхід, творча особистість, творчий стиль поведінки, педагогічна система, системний підхід, майбутній учитель.

Потапенко О. Б., Иванова В. В. Системно-интегративный подход в формировании творческой личности будущего учителя в условиях педагогического вуза.

В статье рассматривается проблема использования системно-интегративного подхода в формировании творческой личности будущего учителя в условиях педагогического вуза. Авторы статьи приходят к выводу о повышении роли требований к воспитанию инициативной, социально активной, творчески направленной личности, способной эффективно решать жизненные проблемы в условиях развития постиндустриального общества; подчеркивается важность активизации и модернизации познавательной деятельности студентов педагогических вузов путем системного анализа организации и содержания учебно-воспитательного процесса, сведения отдельных его аспектов в единую модель.

Ключевые слова: творчество, творческие способности, системно-интегрированный подход, творческая личность, творческий стиль поведения, педагогическая система, системный подход, будущий учитель.

Potapenko O. B., Ivanova V. V. System-integrative approach in the formation of a creative personality of a future teacher in the conditions of pedagogical university.

In the article the problem of using system and integrative approach in the formation of a creative personality of a future teacher in the conditions of pedagogical university was considered. The authors of the article consider that it is nessesary to increase the requirements for education of initiative, socially active, creative-oriented personality that is able to solve the vital problems effectively in the age of post-industrial society development. The importance of activation and modernization of cognitive activity of students of pedagogical universities by the system analysis of education process organization and content and joining some of its aspects in a single model is emphasized.

Modernization of the higher pedagogical education involves improving its contents, reorientation of learning purposes, reorganization of its structure, implementation of new learning technologies, integration and differentiation of knowledge.

The authors of the article pay attention to the disclosure of the content of pedagogical creativity that is an optimal model of teacher's activity that combines the logic of the development of pedagogical science and social contracting in training of creative personality of future teacher.

Based on the analysis of scientific researches a mechanism of pedagogical creativity was 
singled out, ways of systematic and integrated approach in the formation of a creative personality of student in conditions of reorganization of the educational process of pedagogical university were analyzed. New effective ways to improve the educational process connected with the transition from traditional linear models of structuring of knowledge to complicated ones, from static didactic systems to dynamic ones, from standardization of educational content to understanding its plurality and relativity were determined.

An objective regularity of domestic pedagogical education is a complex interaction between different disciplines which inevitably leads to the development of systematic and integrative processes, development and realization of radical new conceptual approaches to modern pedagogical system.

System and integrative approach in pedagogical education covers all directions of the learning process, changes the strict cause and effect dependence on the system of relationships and interrelations, creates a completely new integrated content of learning.

Key words: creativity, creative capabilities, system and integrated approach, creative personality, creative style of behavior, educational system, system approach, a future teacher.

Складні умови розвитку постіндустріального суспільства разом із кризовими явищами в політичній, соціально-економічній, етнокультурній та інших галузях життя висувають вимоги виховання ініціативної, соціально активної, творчо спрямованої особистості, спроможної ефективно розв'язувати життєві проблеми. Саме тому на сучасному етапі реформування вітчизняної освіти значно зростає роль активізації й модернізації пізнавальної діяльності студентів педагогічних вишів шляхом системного аналізу організації й змісту навчально-виховного процесу, зведення окремих його аспектів у єдину модель. Модернізація вищої педагогічної освіти передбачає вдосконалення іiї змісту, переорієнтацію цілей навчання, перебудову її структури, упровадження нових технологій навчання, інтеграцію й диференціацію знань.

У педагогічній науці триває пошук нових ефективних шляхів удосконалення навчального процесу, пов'язаний із переходом від традиційних лінійних моделей структурування знань до складних, від статичних дидактичних систем до динамічних, від стандартизації змісту освіти до розуміння його множинності та відносності [5, с. 51]. Об’єктивною закономірністю вітчизняної педагогічної освіти постає ускладнення взаємодії між різними галузями знань, що неодмінно зумовлює розвиток системно-інтегративних процесів, розроблення й реалізацію принципово нових концептуальних підходів до сучасних педагогічних систем.

Метою статті є теоретичне дослідження можливостей системно-інтегративного підходу у формуванні творчої особистості майбутнього вчителя.

Зміст творчості може бути різним, але соціальна цінність і новизна іiі продукту постають основними характеристиками творчої діяльності. Дані психологічних досліджень свідчать про те, що критерій творчості має бути процесуальним, пов'язаним із особливостями перебіг процесу в цілісній психіці як системі, що породжує активність людини. Аналіз наукової літератури з досліджуваної проблеми дозволяє говорити про те, що педагогічна творчість - це оптимальна модель учительської діяльності, яка сполучає в собі логіку розвитку педагогічної науки й соціальне замовлення на підготовку творчої особистості; це індивідуально-продуктивний процес створення нових або варіювання вже відомими прийомами впливу й взаємодії в нових сполученнях і проблемних формах передачі знань задля отримання творчого результату.

Творча особистість, як уважає С. Сисоєва, є носієм високого рівня знань, відрізняється прагненням до створення нового, оригінального продукту діяльності. Для такої особистості творча діяльність, унаслідок якої виникає нове досягнення, є життєвою необхідністю, а творчий стиль поведінки, нестандартний i часто непередбачуваний найбільш характерним. Творчі здібності є головним показником творчої особистості, бо саме вони забезпечують пошук і впровадження нових способів діяльності, необхідних для 
реалізації іï творчого потенціалу [6, с. 114]. Механізм педагогічної творчості містить у собі риси, що характеризують творчі здібності особистості майбутнього вчителя: абстрагування здатність, відволікаючись від несуттєвого, формувати абстрактні поняття; емоційну стійкість, що забезпечує витримку і самовладання; здатність до ідентифікації себе з іншими; гнучкість мислення - здатність здійснювати почергово ту чи ту розуму операцію; критичність мислення - здатність контролювати інформацію, що надходить, опірність шаблону; легкість генерування ідей - здатність створювати нові ідеї; професійно-педагогічне мислення - здатність аналізувати свою діяльність, відшукувати науково-обгрунтоване пояснення успіхів і невдач, передбачати результати роботи; перенесення досвіду - здатність використовувати засвоєні зразки діяльності в новій ситуації; здатність розвивати ідею уміння всебічно опрацьовувати ідею; творча уява - здатність створювати нові комбінації досвіду; відчуття проблеми - здатність самостійно виявляти проблеми.

Системно-інтегративний підхід у формуванні творчої особистості майбутнього вчителя в умовах організації навчально-виховного процесу педагогічного вишу спирається на органічне поєднання системних та інтегративних елементів у структуруванні змісту навчальних дисциплін. Професійна підготовка майбутнього вчителя має бути адекватною запитам практики й одночасно - більш персоніфікованою, надаючи кожному студенту вже в період навчання можливості оволодіння основами педагогічної майстерності з урахуванням інноваційних технологій. Таку можливість надає врахування всіх складників навчальновиховного процесу.

Системний підхід охоплює всі напрямки навчального процесу - від постановки цілей і конструювання змісту, форм, методів, засобів до перевірки ефективності роботи розроблених навчальних систем. Основні положення системного підходу були розглянуті в роботах Ю. Бабанського, В. Безпалько, Т. Давиденко, Т. Ільїної, О. Пєхоти. Педагогічна система, на думку багатьох дослідників, становить соціально зумовлену цілісність учасників педагогічного процесу, які співпрацюють на основі взаємодії, що дозволяє спрямувати її на формування й розвиток особистості $[8$, с. 9]. Розвиток системного підходу в педагогіці передбачає поєднання безлічі взаємопов'язаних структурних і функціональних компонентів, підпорядкованих меті, завданням і принципам виховання, освіти і навчання підростаючого покоління [8, с. 10].

Отже, педагогічна система - це впорядкована нескінченність взаємопов'язаних елементів, об'єднаних загальним функціонуванням, спільністю мети і єдністю управління, що перебуває у взаємодії з середовищем як цілісна єдність $[4$, с. 6]. В. Безпалько вважає, що системний підхід дозволяє об'єднати в одне ціле об'єктивно взаємопов'язані засоби, методи, форми і процеси, необхідні для створення організованого, цілеспрямованого й умисного педагогічного впливу на формування особистості майбутнього вчителя $[1$, с. 6]. На підставі поданого аналізу наукових тлумачень педагогічних систем і системного підходу можна виявити такі їх характеристики:

1. Системний підхід передбачає врахування сукупності взаємозв'язаних засобів, методів і форм, необхідних для створення організованого, цілеспрямованого й умисного педагогічного впливу на формування особистості.

2. Під час застосування системного підходу наявність взаємопов'язаних компонентів $\epsilon$ важливою умовою їх загального функціонування й органічного поєднання.

3. Базовою системоутворювальною ознакою системного підходу є підпорядкування компонентів меті, змісту, методам, взаємозв'язок діяльності того, хто навчає, і діяльності тих, хто навчається.

У науковій літературі термін «інтеграція» тлумачиться як об’єднання в єдине ціле раніше ізольованих частин, елементів, що супроводжується ускладненням і зміцненням зв'язків та відношень між ними. Категорію інтеграції в педагогіці пов'язують з виникненням якісно нових аспектів у процесі отримання нових знань, установленням істотних зв'язків між речами, процесами та явищами в їх цілісній взаємодії [7, с. 33-34]. У педагогічному словнику інтеграція в навчанні потрактовується як відбір та об'єднання навчального 
матеріалу з різних предметів задля цілісного, системного й різнобічного вивчення важливих наскрізних тем, створення інтегрованого змісту навчання - предметів, які об'єднували б у єдине ціле знання 3 різних галузей [3, с. 124]. На основі численних означень поняття «інтеграція», ми можемо стверджувати, що інтеграцією є процес взаємодії певної кількості структурних елементів із заданими властивостями, який супроводжується встановленням, ускладненням, зміцненням істотних зв'язків між цими елементами, а результатом такої взаємодії $\epsilon$ формування інтегрованого об’єкта (цілісної системи) 3 якісно новими властивостями [5, с. 53].

На основі переваг системно-інтегративного підходу певний інтерес становить доволі специфічний метод кон'юктивного аналізу. Його практичне використання в структуруванні змісту навчання та організації навчального процесу передбачає перехід від концепції різнопредметних уявлень до єдиного інтегрованого погляду на всю освітньо-дидактичну систему [5, с. 52]. У процесі інтеграції сувора причинно-наслідкова зумовленість змінюється системою взаємовідношень і взаємозв'язків, коли елементи одного об'єкта співвідносяться і взаємодіють зі структурою іншого, а наслідком такого взаємопроникнення стає не просто сукупність подібних і однорідних елементів з можливим покращенням якості обох об'єктів, а новий об'єкт з новими властивостями [7, с. 35]. Нині все більше дослідників висновують, що виховання й освіта $є$ не що інше як оволодіння культурою (особливо, коли під культурою розуміється накопичений досвід людства або набутий рівень майстерності в окремій сфері діяльності) і культурологія становить не просто споріднену з педагогікою галузь знань, а $\dddot{11}$ методологічну основу, важливий складник педагогічної культури вчителя [2].

Для успішної реалізації концепції системно-дидактичної інтеграції слід дотримуватися базових принципів дидактики. Наочність, системність, науковість, свідомість і грунтовність знань, наступність у навчанні становлять традиційну основу вимог навчання. Особливо зростає роль принципу системності, спрямованого на формування цілісної системи предметних знань. Цьому сприяє науково-методологічне об'єднання інформаційного забезпечення кількох (як правило, двох) навчальних дисциплін, що дозволяє більш оперативно й науково грамотно на рівні причинно-наслідкових зв'язків пояснювати особливості теоретико-практичної підготовки до педагогічної діяльності й ефективно формувати інтелектуальні, моральні, естетичні вміння й навички майбутніх учителів. Так, у процесі вивчення навчальної дисципліни «Методика виховної роботи», яка безпосередньо спрямована на підготовку студентів до проходження педагогічної практики, органічно поєднується навчальний матеріал з курсів педагогіки, історії педагогіки, психології, соціології, філософії, етики.

Інтегративні дидактичні системи, основу яких складають ідеї природної інтеграції та синергетики (нелінійне мислення, яке здатне сприймати істинну реальність нескінченної змінюваності світу) здатні значно активізувати пізнавальну діяльність студентів, розвинути їхнє мислення. Головною особливістю такого підходу є поділ навчального матеріалу не ззовні, а зсередини. У межах інтегративних дидактичних систем застосовуютть низку законів: корелятивність - елементи інтеграції мають властивості, які забезпечують їх здатність до узгодженої взаємодії; імперативність визнає наявність системно-структурного характеру зінтегрованого об’єкта; доповнювальність - інтегративні процеси спричиняють процеси диференціації (і навпаки) [5, с. 56-58].

Отже, використання системно-інтегративного підходу у формуванні творчої особистості майбутнього вчителя в умовах педагогічного вишу передбачає врахування сукупності взаємозв'язаних форм, методів і засобів організації навчально-виховного процесу, їх загальне функціонування й органічне поєднання. Логіка використання такого підходу в навчанні студентів спрямована на формування в них цілісної системи предметних знань із використанням законів кореляції й імперативності.

\section{Література}

1. Беспалько В. П. Слагаемые педагогической технологии / $\quad$ В. П. Беспалько. Москва : Педагогика, 1989. - 192 с. 2. Буряк В. К. Педагогічна культура : методологічний 
аспект / Володимир Костянтинович Буряк.- Київ: Деміург, 2005.- 232 с. 3. Гончаренко С. У. Український педагогічний словник / Семен Устимович Гончаренко. Київ : Либідь, 1997. - 376 с. 4. Ильина Т. А. Структурно-системный подход к организации обучения / Т. А. Ильина. - Москва : Знание, 1982. - 72 с. 5. Козловська І. М. Дидактична інтегрологія : сутність, теоретичні основи, застосування / I. М. Козловська // Педагогіка i психологія. - 2001. - № 1.- С. 51-60. 6. Освітні технології : [навчально-методичний посібник] / [за ред. О. М. Пехоти]. - Київ : А.С.К., 2002. - 256 с. 7. Сова М. Філософськокульторологічні основи інтеграції знань / Маргарита Сова // Рідна школа. - 2002. - № 5. С. 33-36. 8. Шамова Т. И. Управление образовательными системами / Т. И. Шамова.Москва : Академия, 2003. - 384 с.

УДК 378.14:622.007.2

Микола Ступнік, Володимир Моркун, Зінаӥда Бакум, Вікторія Ткачук

\section{КОНЦЕПЦІЯ ПІДГОТОВКИ ГІРНИЧОГО ІНЖЕНЕРА В СИСТЕМІ НЕПЕРЕРВНОЇ ОСВІТИ (ШКОЛА - ВНЗ - ПІДПРИСМСТВО)}

Ступнік М. І., Моркун В. С., Бакум 3. П., Ткачук В. В. Концепція підготовки гірничого інженера в системі неперервної освіти (школа - ВНЗ - підприємство).

У статті розроблено концепцію підготовки гірничого інженера в системі неперервної освіти. Визначено етапи означеної підготовки: загальноосвітній заклад, вищий навчальний заклад, підприємство. Обгрунтовано значення профорієнтаційної роботи, дидактичні засади фахової підготовки майбутніх інженерів в умовах сучасного вишу, а також порушено проблеми адаптації випускників гірничих факультетів на підприємстві.

Ключові слова: підготовка гірничого інженера, система неперервної освіти, етапи підготовки гірничого інженера, організація профорієнтаційної роботи, фахова підготовка, адаптація гірничих інженерів на підприємстві.

Ступник Н. И., Моркун В. С., Бакум 3. П., Ткачук В. В. Концепция подготовки горного инженера в системе непрерывного образования (школа - вуз - предприятие).

В статье разработана концепция подготовки горного инженера в системе непрерывного образования. Определены этапы такой подготовки в общеобразовательном заведении, высшем учебном заведении, на предприятии. Обосновано значение профориентационной работы, дидактические основы профессиональной подготовки будущих инженеров в условиях современного вуза, а также рассмотрены проблемы адаптации выпускников горных факультетов на предприятии.

Ключевые слова: подготовка горного инженера, система непрерывного образования, этапы подготовки горного инженера, организация профориентационной работы, профессиональная подготовка, адаптация горных инженеров на предприятии.

Stupnik M. I., Morkun V. S., Bakum Z. P., Tkachuk V. V. The concept of a mining engineer training in the lifelong learning system (school - higher educational institution - enterprise).

In the article the concept of a mining engineer training in the lifelong learning system has been developed. The attention is focused on the fact that among urgent problems the effective training and professional development of mining engineers are of key importance because of a severe shortage of highly qualified mining professionals. Stages of training have been defined. They are general educational institution, higher educational institution, enterprise. The value of occupational guidance, didactic principles of future engineers training in the condition of modern university have been proved. The problems of adaptation of mining faculty graduates at the enterprise have been discussed.

The first stage in the system of mining engineer training is educational institutions where one of the main objectives is ensuring the social adaptation of students, their adjustment to real 